\title{
ANÁLISE DOS LIMITES DA OBEDIENCIA HIERÁRQUICA NO DIREITO PENAL A LUZ DO EXPERIMENTO DE MILGRAM
}

\author{
Carlos Lélio Lauria Ferreira ${ }^{1}$ \\ Gina Marcilio Vidal Pompeu ${ }^{2}$
}

\section{Resumo}

Por meio do presente artigo, elabora-se análise dos limites da obediência hierárquica no Direito Penal à luz do experimento de Stanley Milgram. Justifica-se a escolha do tema por entender-se que se trata de questão desconsiderada no mundo jurídico-penal brasileiro e, de certa forma, pouco explorada no meio acadêmico. O objetivo da pesquisa é mostrar, inicialmente, que o Código Penal brasileiro incorre na omissão sobre aspectos relevantes que justificam a isenção de pena do agente. Para demonstrar essa incongruência, é feita comparação entre a lei penal, a doutrina e a jurisprudência criminal com os resultados do experimento de Milgram, dando-se ênfase para os limites dentro dos quais é possível aceitar-se o reconhecimento de uma excludente de culpabilidade sob o pálio da obediência hierárquica. O problema constatado na abordagem é a previsão sobre a obediência hierárquica no Direito Penal comum e no militar, exsurgindo daí a necessidade de questionar-se o reconhecimento de uma excludente de culpabilidade sob o pálio da obediência hierárquica. A metodologia utilizada é a analítica, empírica, com conceitos jurídicos e normativos no âmbito do Direito e da Psicologia. Os conceitos utilizados levam em consideração a realidade social, bem como o entendimento doutrinário e jurisprudencial sobre a matéria. Espera-se obter como resultado do trabalho o esclarecimento da importância da correta aplicação do instituto da obediência hierárquica, considerando a mudança na lei penal.

\footnotetext{
${ }^{1}$ Doutorando em Direito Constitucional no Centro Universitário de Ensino Superior do Amazonas - CIESA e Universidade de Fortaleza; especialista em Direito Público pela Fundação Getúlio Vargas e em Direito Penal e Processual Penal pela Universidade Cândido Mendes; Pós-Graduado em Teologia Contemporânea pela Faculdade Claretiano; Procurador de Justiça do Ministério Público do Estado do Amazonas. Coordenador Executivo do Comitê Permanente da América Latina para Revisão e Atualização das Regras Mínimas das Nações Unidas para Tratamento dos Presos. Manaus-AM, Brasil. E-mail: lelio@argo.com.br ${ }^{2}$ Graduada em Direito pela Universidade Federal do Ceará. Mestre em Direito (Direito e Desenvolvimento) pela Universidade Federal do Ceará (1994) e Doutora em Direito pela Universidade Federal de Pernambuco (2004). Pós-Doutora pela Universidade de Lisboa. Coordenadora e Professora do Programa de Pós-Graduação em Direito Constitucional da Universidade de Fortaleza (UNIFOR), Mestrado e Doutorado. Consultora Jurídica da Assembleia Legislativa do Estado do Ceará. E-mail: ginapompeu@unifor.br
} 
Palavras-chave: Direito Penal; Culpabilidade; Obediência hierárquica; Experimento de Milgram.

\section{INTRODUÇÃO}

A reflexão apresentada neste artigo tem o propósito de elaborar análise crítica da natureza jurídica da obediência hierárquica no Direito Penal brasileiro, com destaque para o Direito Penal Militar, à luz do experimento realizado pelo psicólogo americano Stanley Milgram, na Universidade de Yale, nos Estados Unidos, em 1974.

É certo que as contemporâneas correntes de Filosofia do Direito propõem um estudo interdisciplinar. Assim, no presente artigo, pretende-se estabelecer a conexão entre Direito e Literatura, e a partir daí alcançar a melhor compreensão dos limites da obediência hierárquica, questão jurídica relevante no Direito Penal. De fato, a interpretação do roteiro de um filme $e^{3}$ ou de um texto literário como "Obediência à autoridade", de Stanley Milgram, permite que se tenha um novo olhar para questões jurídicas complexas. Embora não seja classificada como ciência, a Literatura é fundamental para compreensão do Direito. Os dois campos do conhecimento se aproximam especialmente quanto às técnicas de análise.

Convém esclarecer nesta introdução que o tratamento dado à obediência hierárquica no Código Penal brasileiro incorre na omissão sobre aspectos relevantes que justificam a isenção de pena do agente. Para demonstrar a incongruência, comparam-se a lei penal, a doutrina e a jurisprudência criminal com os resultados do experimento de Milgram, dando-se ênfase aos limites dentro dos quais é possível aceitar-se o reconhecimento de excludente de culpabilidade sob o pálio da obediência hierárquica.

A questão examinada e que constitui o problema enfrentado neste artigo é desafio para os aplicadores da lei penal brasileira, sobretudo pela ausência de debate e abordagem acanhada da doutrina penal. O que se põe em pauta, nuclearmente, portanto, é que não se pode admitir a exclusão da culpabilidade de agente que pratica um fato em estrita obediência à ordem não manifestamente ilegal de superior hierárquico, considerando-se, estritamente, aspectos relacionados à legalidade ou ilegalidade da ordem emitida, como previsto no Código Penal brasileiro e sustentado pela quase unanimidade da doutrina.

Entende-se, em harmonia com os resultados do experimento de Milgram, que ato realizado obedecendo

\footnotetext{
${ }^{3}$ Em observação sobre o cinema como prática social, Turner (1997) lembra que os teóricos do cinema têm tido muito interesse pela psicanálise, considerando que a natureza da fascinação do cinema - sua capacidade de dissolver as fronteiras do real - é mais um convite para a psicanálise.
} 
a ordens é, psicologicamente, de caráter profundamente diferente da ação espontânea, o que, em outras palavras, significa dizer que uma pessoa que, por convicção, odeia roubar, matar e assaltar pode ver-se a executar alguns desses atos com relativa facilidade ao cumprir as ordens de uma autoridade, isto é, o comportamento que é inimaginável em uma pessoa que esteja agindo por conta própria pode ser executado, sem hesitação, quando feito em obediência a ordens. Acredita-se, portanto, que a omissão legislativa incentiva prática de atos bárbaros sob o manto da impunidade.

Ressalta-se, neste trabalho, o valor do ensaio científico destinado à verificação de um fenômeno na história da pesquisa científica, com a observação de que um experimento científico nunca decide debate epistemológico, como proposto com esta divergência.

\section{A OBEDIÊNCIA HIERÁRQUICA NO DIREITO PENAL COMUM}

O instituto da obediência hierárquica é tratado no art. 22 do Código Penal brasileiro nos seguintes termos: se o fato é cometido sob coação irresistível ou em estrita obediência à ordem, não manifestamente ilegal, de superior hierárquico, só é punível o autor da coação ou da ordem. Extrai-se do referido dispositivo que o subordinado que cumpre ordem que não seja manifestamente ilegal, isto é, aparentemente legal, emanada de seu superior hierárquico, tem sua culpabilidade excluída, ficando isento de pena.

Dessa forma, o juiz que manda um policial militar algemar um advogado que, no calor do embate judiciário, irrogou ofensa contra a parte adversa desconsidera que o advogado detém imunidade judiciária, e não pode ser preso em flagrante pela prática do ato. O subordinado (policial), então, cumpre ordem ilegal, mas, diante de seus parcos conhecimentos jurídicos, a ordem era aparentemente legal. Fácil observar, portanto, que o critério adotado pela lei penal brasileira peca pela omissão e legitima a ação do agente que comete atrocidade fundada na "certeza" da legalidade da ordem.

Esclarecedoras, porém insuficientes, são as lições de Nucci (2017) ao afirmar que há requisitos que caracterizam a obediência hierárquica ${ }^{4}$. Em primeiro lugar, há a existência de ordem não manifestamente ilegal, ou seja, de duvidosa legalidade, o que caracteriza a excludente como misto de inexigibilidade de outra conduta com erro de proibição. Evidentemente, a ordem precisa ser emanada de autoridade competente. Quando, excepcionalmente, cumpre-se ordem de autoridade incompetente, pode-se configurar "erro de proibição escusável". Além disso, há necessidade de três partes envolvidas: superior, subordinado e vítima. Exige-se, ainda,

\footnotetext{
${ }^{4}$ Reconhece-se a obediência hierárquica quando não se pode exigir do agente comportamento conformado com o direito dentro de uma relação de Direito Público.
} 
relação de subordinação hierárquica entre o mandante e o executor, em direito público ${ }^{5}$, tudo de acordo com estrito cumprimento da ordem ${ }^{6}$. É importante, principalmente, verificar se há proporcionalidade entre o comando dado e o resultado a ser atingido.

Em importante diferenciação entre a coação irresistível e a obediência à ordem, Pires (1973) assevera que em ambas as circunstâncias há impossibilidade de conformar os comportamentos ao ordenamento jurídico, mas, enquanto na ordem de superior hierárquico tal impossibilidade resulta da suposição por parte do agente de que pratica ato lícito, na coação irresistível, embora o agente saiba que pratica ato ilícito, outro procedimento não se lhe exige juridicamente? . O autor fala em "suposição", mas também é omisso ao não enfrentar questão relevante para o Direito Penal quanto à gravidade do ato praticado em obediência à ordem.

No Direito Penal italiano, o cumprimento de ordem emanada de superior hierárquico é previsto como causa excludente de ilicitude. É a situação em que o agente está diante da necessidade de cumprir a ordem ou obedecer ao disposto na lei, considerando que a ordem não é manifestamente ilegal, na linha do entendimento de Basileu Garcia ${ }^{8}$ e diferente do que sustentam Vargas ${ }^{9}$ e Fragoso ${ }^{10}$, no sentido de que haveria, na hipótese de obediência à ordem não manifestamente ilegal, erro de proibição, pois se daria juízo equivocado sobre a licitude do ato a ser cumprido em obediência à ordem do superior hierárquico.

Contudo, a questão deve ser examinada por outro ângulo, segundo Reale Júnior (2012), ao afirmar que a ordem manifestamente ilegal não cabe ser cumprida ${ }^{11}$, pelo fato de que, se quem a emite não tem competência para tal ou se não é atribuição do receptor da ordem realizar a ação determinada, ou seja, se o agente não tem

\footnotetext{
${ }^{5}$ Nucci (2017) ressalta que não há possibilidade de sustentar a excludente na esfera do Direito Privado, tendo em vista que somente a hierarquia no setor público pode trazer graves consequências para o subordinado que desrespeita seu superior (no campo militar, até a prisão disciplinar pode ser utilizada pelo superior, quando não configurar crime), CPM, art. 163: "Recusar obedecer a ordem do superior assunto ou matéria de serviço, ou relativamente a dever imposto em lei, regulamento ou instrução: Pena - detenção, de um a dois anos, se o fato não constitui crime mais grave".

${ }^{6}$ Mais uma vez é salientado pelo autor que, em se tratando de ordem de duvidosa legalidade, é preciso, para valer-se da excludente, que o subordinado fixe os exatos limites da determinação que lhe foi passada, já que o exagero descaracteriza a excludente, pois se vislumbra ter sido exigível do agente outra conduta, tanto que extrapolou o contexto daquilo que lhe foi determinado por sua própria conta - e risco. Neste sentido é o disposto no Código Penal Militar: "Se a ordem do superior tem por objeto a prática de ato manifestamente criminoso, ou há excesso nos atos ou na forma de execução, é punível também o inferior” (art. 38, $\$ 2^{\circ}$, grifamos). O problema não enfrentado pelo autor é que, se a lei penal é permissiva quanto ao erro do agente em relação ao que seja "ordem manifestamente ilegal", deveria exigir, por simetria, discernimento do agente do que vem a ser "ato manifestamente criminoso".

${ }^{7}$ Em tal oportunidade, diz Aníbal Bruno que "o que acontece é um erro de Direito, excepcionalmente tomado como causa capaz de dirimir a culpabilidade do agente. Aquele que dá execução à ordem atua sem culpabilidade, certo como está de que obedece a um comando legítimo e de que é seu dever obedecer-lhe".

${ }^{8}$ GARCIA, B. Instituições de Direito Penal. v. 1, tomo I. 5. ed. São Paulo: Max Limonad, 1980.

${ }^{9}$ VARGAS, J. C. Instituições de Direito Penal. Parte geral, tomo I. Belo Horizonte: Del Rey, 1977.

${ }^{10}$ FRAGOSO, H. C. Jurisprudência criminal. Rio de Janeiro: Forense, 1982; Lições de Direito Penal. 9. ed. Rio de Janeiro: Forense, 1995.

${ }^{11}$ A ordem será manifestamente ilegal - é de ser contestada. O temor pode caracterizar uma situação de coação, mas não obediência hierárquica.
} 
condição de desrespeitar o comando ilegal, é de se analisar a configuração de situação de necessidade por coação e, nas circunstâncias, se a ação não é reprovável, e sim válida, exclue-se a culpabilidade; nesse caso, se o cumprimento da ordem for reprovável, respondem pelo crime o executor da ação e o autor da ordem a ser executada.

Assim, acrescenta Reale Júnior (2012), mesmo que o inferior hierárquico tenha dúvida e possa questionar a legalidade, prevalece o dever de obediência, em razão do que é ação praticada destituída de ilicitude, pois não é possível impor-se o dever de obediência ao superior hierárquico quando a ordem não for manifestamente ilegal e, doutra parte, reputar a prática da obediência, a realização da ação ordenada, crime ${ }^{12}$. $\mathrm{O}$ inferior hierárquico ao realizar a ação ordenada não o faz por imaginar que não seja proibida, mas sim para obedecer à ordem do superior, sendo, portanto, causa de justificação ou excludente de ilicitude ${ }^{13}$.

Como demonstrado mais adiante, os doutrinadores não enfrentam a questão nuclear do instituto da obediência hierárquica: omissão relevante na lei penal quanto ao comportamento do agente, passível de legitimação de atos cruéis cometidos em obediência à ordem. Nesse caso, pelo que sustentam os autores, a situação tornar-se-ia mais esdrúxula: a atrocidade não isentaria o agente de pena, mas excluiria a própria ilicitude da conduta.

Entenda-se "ordem de superior hierárquico" por determinação originada de alguém no exercício de cargo ou função de natureza pública, cujo destinatário é seu subordinado hierárquico, para executar uma ou mais ações ou omissões. Considerando que se exige o estabelecimento de relação de Direito Público, não há de se falar em obediência hierárquica em relação que não envolva servidores ou agentes do serviço público. Em outras palavras, a obediência que tem significado para o Direito Penal é a obediência hierárquica de Direito Público, e não se inclui, nesse caso, a relação de natureza laboral, doméstica ou eclesiástica ${ }^{14}$. No que diz respeito às ordens legais advindas do superior hierárquico, não há relevância para o Direito Penal por não constituírem ilícito penal.

Como se pode observar, mesmo a despeito de se considerar a insuficiência de critérios da lei penal, é essencial que se faça a distinção entre ordem manifestamente ilegal e ordem não manifestamente ilegal. A primeira não apresenta nenhuma dificuldade de identificação de sua indiscutível ilegalidade. Na segunda, a ilegalidade não é patente, clara, por isso é discutível.

A título de exemplo da primeira, Teles (2006) cita o caso do delegado de polícia que ordena ao agente da carceragem que mate o preso da cela no 3 porque ele é portador do vírus da AIDS ou que estupre a presa da cela

\footnotetext{
${ }^{12}$ A estrita obediência à ordem não manifestamente ilegal é causa de exclusão da ilicitude (TACrSP, RT606/342).

${ }^{13}$ Sobre a doutrina que perfilha este entendimento, vide: RIVACOBA Y RIVACOBA, M. La obediencia jerárquica en el Derecho Penal.Valparaiso: Edeval, 1969, p. 66 e seguintes.

${ }^{14}$ Não há, em consequência, relação hierárquica nas hipóteses de temor reverencial entre pais e filhos ou mesmo entre líderes de denominações religiosas, comunidade eclesial e seus fiéis.
} 
feminina porque ela o ofendeu. Essas ordens são manifestamente ilegais, afirma o autor, de modo que, se o carcereiro cumprir qualquer delas, não poderá alegar ter agido ao amparo da exculpa da obediência hierárquica.

No segundo caso, o autor oferece como modelo um promotor de justiça que determina ao secretário recém-empossado no gabinete da promotoria que, antes de iniciar-se a audiência, vá à sala das testemunhas e determine a uma delas que venha a falar-lhe e, caso ela se recuse, traga-a presa em flagrante de crime de desobediência. Essa ordem, à primeira vista, não parece ilegal, apesar de sê-la, sustenta o autor. O promotor de justiça não tem poder para mandar vir a sua presença quem quer que seja, mormente por meio de chamado verbal, por um simples funcionário burocrático, e fora de qualquer processo ou procedimento legalmente instaurado ${ }^{15}$.

Qualquer atividade desenvolvida no âmbito estatal e sujeita a ordem hierárquica é passível de temor reverencial, que consiste no medo ou receio entre os participantes de uma relação em que esteja presente o dever de obedecer. Há, de qualquer modo, presunção de legalidade nas ordens superiores, as quais em tese estão em conformidade com a ordem jurídica, suposição que se estende à falta de consciência da ilegalidade da ordem, o que, no caso concreto, permite que o ato seja desculpável. Ressalte-se, entretanto, entendimento aqui expressado quanto à omissão legislativa e silêncio na doutrina em relação à conduta do agente que executa a ordem.

Com o intuito de fundamentar os argumentos sustentados no presente artigo, convém destacar que a obediência hierárquica tem estreita relação com os institutos do erro de tipo e do erro de proibição ${ }^{16}$. De fato, aquele que cumpre ordem de superior hierárquico o faz convicto da legalidade do que deve ser executado, ao mesmo tempo em que lhe é permitido fazer um juízo de valor sobre a legalidade da ordem.

Ao realizar abordagem sobre o tema, Mayrink da Costa (2005) apresenta três soluções para a vexata quaestio: (a) o sistema de obediência passiva, em que se exclui a possibilidade de o inferior indagar a legalidade da ordem recebida; (b) o sistema da externa das baionnettes inteligentes, no qual tem o direito de discutir a ordem e de recusar obediência, quando ilegal; (c) o sistema intermediário, em que, cumprida a ordem manifestamente ilegal, a circunstância da obediência apenas atenuará a pena de incorrer em delito, como resultado do cumprimento da ordem (atenuante da errada compreensão da lei penal). $\mathrm{O}$ autor estabelece, ainda, três princípios

\footnotetext{
${ }^{15} \mathrm{O}$ autor faz um esclarecimento: para o servidor público recentemente ingressado no serviço público, sem qualquer conhecimento das regras processuais e, mesmo, de Direito Administrativo, aquela ordem recebida é legal. Recebendo-a de seu superior, um promotor de justiça - alguém que lhe parece ser um "homem de lei", aliás, é o fiscal dela -, jamais pensaria ser uma ordem contra lei, de sorte que, em sua consciência, a ordem recebida é perfeitamente legal. Se ele vai à sala das testemunhas, emite a convocação e a testemunha, recusando-se a acompanhá-lo, é trazida coercitivamente, terá havido, a toda evidência, um fato típico de constrangimento ilegal, definido no art. 146 do Código Penal, quando não o de sequestro, definido no art. 148, Código Penal.

${ }^{16}$ Álvaro Mayrink da Costa traz a lume elucidação quanto aos dois tipos de erros: o erro é de proibição quando o subordinado acredita erroneamente que se the manda praticar ato justo (v.g.: se o Delegado Caio determina aos agentes da autoridade Tício e Semprônio que prendam Mélvio em seu trabalho por mera suspeita de furto e o coloquem em uma cela do distrito policial para "averiguações", Tício e Semprônio não podem alegar a excludente de culpabilidade do erro de proibição invencível, visto que se trata de notória ilicitude policial). Poderá ocorrer erro de tipo, quando Caio imagina, por erro plenamente justificado pelas circunstâncias, situação factual que, ocorrendo, tornaria a conduta legítima.
} 
básicos quanto à responsabilidade do inferior que dá cumprimento a ordem ilegal: (a) obediência absoluta, em que o subordinado deve cumprir sem discutir a ordem do superior hierárquico; (b) obediência relativa, em que o subordinado deve negar o cumprimento à ordem manifestamente ilegal ${ }^{17}$; (c) obediência refletiva, em que o subordinado deve representar ao superior a ilegalidade da ordem - todavia, se reiterada, deve cumpri-la, liberando-se da responsabilidade que incidirá unicamente no superior.

Com base nas questões suscitadas por Mayrink da Costa (2005), faz-se algumas observações em forma de resumo: só haverá causa de exculpação quando a dependência hierárquica entre o superior que manda e o subordinado que obedece seja de caráter oficial; no caso do subordinado que tenha a faculdade de analisar a ordem, se constatada sua ilicitude, ao cumpri-la, responde pelo ato praticado; na hipótese do subordinado que tenha a faculdade de avaliação e deixa de fazê-la, cumprindo-a, se a ordem é ilícita, responderá a título de negligência; quando o subordinado não tem a faculdade de avaliação, não será reprovável com fulcro na obediência hierárquica que justifica seu comportamento.

Sobre o assunto, oportuna a opinião de Junqueira (2017) no sentido de que não se exige do funcionário público que proceda a exame detalhado e minucioso das ordens que recebe. É esse o fundamento da inculpabilidade do agente, e não qualquer suposto dever de obediência (que inexiste; se existisse seu cumprimento seria, mais uma vez, caso estrito do dever legal). Portanto, caso a ilegalidade da ordem "salte aos olhos", ou seja, não exija nenhum esforço anormal do funcionário público para percebê-la, desaparece por completo a razão de ser da causa de exculpação.

Para ilustrar a reflexão aqui pretendida, reproduz-se o exemplo pensado por Greco (2014) do detetive que, a mando da autoridade policial, espanca o preso a pretexto de conseguir a confissão. Percebe-se, desde logo, que a ordem emanada da autoridade é manifestamente ilegal e, sendo cumprida, não permite a aplicação do art. 22 do Código Penal brasileiro em benefício daquele que a cumpriu ${ }^{18}$. Como descrito por Martinelli (2017), no Brasil não se aplica a teoria da "obediência cega", segundo a qual a ordem do superior deve ser cumprida pelo subordinado sem questionamentos. Ao contrário, a ilicitude da ordem retira a obrigação de seu cumprimento. Importante ressaltar o que se sustenta nesta análise crítica: o que deve impedir ou autorizar a isenção da pena ou a exclusão da ilicitude para o posicionamento mais radical não é a avaliação da legalidade ou ilegalidade da ordem,

\footnotetext{
${ }^{17}$ A ordem deve ser emanada de superior hierárquico (autoridade pública) do agente e só isenta o agente se não for manifestamente ilegal (TARS, RT579/393; TACrSP, RT490/331; TJSP, Ap. 236.356-3/1, In Bol. IBCCr 89/44I).

${ }^{18}$ Inviável o reconhecimento da excludente da culpabilidade de obediência hierárquica para o delito de tortura, em sua modalidade omissiva, na estrita via do habeas corpus, desprovida de dilação probatória, quando não evidenciada a legalidade da ordem. As teses de ausência de dolo e de impossibilidade física de agir esbarram nos estreitos limites do remédio constitucional, eis que demandam o profundo revolvimento do conjunto fático-probatório colhido nos autos da ação penal cognitiva ajuizada pelo Ministério Público. Presentes indícios suficientes de autoria com relação ao paciente, consoante os elementos de convicção até então colhidos, há justa causa para sua persecução penal em juízo. Precedes. Ordem denegada (STJ, HC 93.533/GO 2007/0255315-1, Relator (a) Jane Silva (Desembargadora Convocada do TJMG), 60 T., j. em 24-2-2008).
} 
mas a avaliação psicológica da conduta do agente em relação à ordem executada e seu resultado.

A natureza jurídica do instituto da obediência hierárquica é ambígua na visão de Queiroz (2005) porque, embora a doutrina o tenha como especial causa de erro de proibição, não se pode ignorar que o subordinado, em tais casos, encontra-se também no estrito cumprimento - putativo - de dever legal, porque imagina que ao obedecer à ordem está cumprindo seu dever legal de funcionário subordinado. O exemplo da excludente de culpabilidade apresentado pelo autor é o do inexperiente policial que realiza, a mando de delegado de polícia, prisões ilegais. Como assinala Gomes (2007), sendo a ordem não manifestamente ilegal ${ }^{19}$, como no caso do superior militar que manda inferior matar perigoso "bandido" que fugia, só responde pelo crime quem deu a ordem, não o inferior; de qualquer modo, o inferior deve cumprir a ordem estritamente, não podendo haver abuso. Nos dois casos, entende-se que há necessidade de avaliação psicológica da conduta do agente em relação à ordem executada e seu resultado.

Em comentário a respeito do erro sobre a legalidade da ordem, Delmanto (2007) esclarece que, se a ordem era ilegal, mas não manifestamente, e houve erro justificável sobre o elemento constitutivo que é a ilegalidade, absolve-se, pois agiu iludido (CP, art. 20) pelas circunstâncias de fato (TACrSP, Julgados 84/200). Com o mesmo entendimento, Milhomen (2014) afirma tratar-se de caso especial de erro de proibição, consistente na obediência à ordem não manifestamente ilegal de superior hierárquico, tornando viciada a vontade do subordinado, o que afasta a exigência de conduta diversa. Em suma: supondo obedecer a ordem legítima do superior, o agente pratica o fato incriminado. Esse é também o posicionamento de Gonçalves (2015). Percebe-se que a doutrina pouco avança sobre os aspectos fundamentais que norteiam a obediência hierárquica no Direito Penal brasileiro.

Com pouca variação, mas elucidativo, Flores (2016) utiliza como exemplo o caso de delegado que, após interrogar o preso, determina ao agente de polícia que o recolha na carceragem da delegacia. Ocorre que, posteriormente, o agente vem a descobrir que não se tratava de preso, mas sim de devedor do delegado. Nesse caso, o agente de polícia, subordinado ao delegado, ficará isento de pena. Entretanto, no mesmo exemplo, se o delegado pedir ao agente de polícia que leve o interrogando para a "sala da memória" (local onde ocorrem a tortura e a confissão), e que somente o traga de volta quando este se lembrar do crime, tanto o delegado quanto o agente de polícia, nesse caso, deverão responder pelo crime, havendo somente atenuação na pena do subordinado. Essa é a questão essencial que se busca esclarecer e que os dois exemplos não atacam: os limites da obediência hierárquica no Direito Penal, além da análise da legalidade ou ilegalidade da ordem.

\footnotetext{
${ }^{19}$ Habeas Corpus. Trancamento da ação penal. Paciente policial militar que descumprir ordem de superior hierárquico, consistente em se dirigir à cadeia pública, no intuito de reforçar a guarda. Alegação de ilegalidade da ordem descumprida, ao argumento de incompatibilidade com as atribuições da função policial militar. Inexistência. Ordem não manifestamente ilegal. Ordem denegada.
} 
Um exemplo didático é apresentado por Barros (2016): o delegado de polícia determina ao agente que exija do autor de determinado crime certa quantia, a fim de não ser instaurado inquérito policial. Nesse caso, os dois respondem por crime de concussão $(\mathrm{CP}$, art. 316, caput). Em relação ao subordinado, há atenuante genérica $(\mathrm{CP}$, art. 65, III, c). Outro exemplo é trazido por Nelson Hungria: um bisonho soldado de polícia, por ordem do comandante da escolta, mata com tiro de fuzil supondo agir por obediência devida o criminoso que tenta fugir ou opõe resistência passiva ao mandado de prisão. Nesse caso, aplica-se o disposto no art. 22, 1ª parte do CP. Embora a conduta do subordinado constitua fato típico e antijurídico, ele não é culpado, em face de incidir relevante erro de proibição. Diante disso, o subordinado não responde pelo crime, completa o autor. Nos dois exemplos, vê-se que a doutrina se limita aos aspectos rasos da natureza jurídica da obediência hierárquica.

\section{A OBEDIENCIA HIERÁRQUICA NO DIREITO PENAL MILITAR}

O tratamento da obediência hierárquica no Código Penal Militar exige, de início, fazer distinção entre o funcionário civil e o funcionário militar. De acordo com Bitencourt (2007), o funcionário civil não discute a oportunidade ou conveniência, mas discute a legalidade. E a ilegalidade pode decorrer, por exemplo, do descumprimento de formalidade. A ordem pode ser ilegal porque não obedece à forma estabelecida em lei. Basta isso e já será ilegal. O funcionário civil, subalterno, não é obrigado a cumprir ordem ilegal. Ademais, se representar qualquer prejuízo a terceiro, será tão responsável quanto o superior.

Agora, no caso do militar, a situação é completamente diferente. Ele não discute a legalidade porque tem o dever legal de obediência, e qualquer desobediência pode constituir crime de insubordinação (art. 163 do CPM). O subalterno militar não é culpado, qualquer que seja sua convicção sobre a ilegalidade da ordem. Pelo crime eventualmente decorrente só responde o autor da ordem ${ }^{20}$. E acrescenta que o Código Penal Militar, diferentemente do Código Penal, estabelece, implicitamente, apenas que o militar não deve obedecer à ordem manifestamente criminosa $\left(\operatorname{art} .38, \$ 2^{\circ}\right)$. A questão é completamente diferente ${ }^{21}$. Evidentemente, seria absurdo afirmar que alguém tem o dever de obedecer à ordem criminosa. Aí, seria a inversão total das instituições políticas e democráticas ${ }^{22}$.

(HC 101564, Relator (a): Min. Gilmar Mendes, Segunda turma, julgado em 30/11/2010).

${ }^{20}$ MUNHOZ NETTO, Alcides. A ignorância em matéria de antijuridicidade em matéria penal. Rio de Janeiro: Forense, 1978, p. 138.

${ }^{21}$ No entanto, como diz o autor, a culpabilidade do subordinado militar pode ser excluída pela coação irresistível. Por exemplo, o agente militar sabe que a ordem é manifestamente criminosa, mas é coagido a cumpri-la. Se a ameaça ou a ordem representar efetivamente uma coação irresistível, o subordinado militar será beneficiado pela primeira parte do art. 22, isto é, pela excludente da coação irresistível, mas não pela subordinação hierárquica.

${ }^{22}$ MARTINS, Salgado. Direito Penal, introdução e parte geral. São Paulo: Saraiva, 1974, p. 248. 
Com efeito, a obediência hierárquica deve estar presente na vida militar, por constituir a hierarquia princípio básico e constitucional das Forças Armadas, adverte Figueiredo (2009), ou seja, no âmbito militar, a subordinação e a obediência afiguram-se como regras mais rigorosas do que no campo civil, devido à indispensável manutenção da ordem. A autora traz à discussão a possibilidade de a excludente especial de ilicitude ser aplicada no caso do comandante de navio, aeronave ou praça de guerra, dos responsáveis pelo bom desempenho da tropa, bem como a admissão incondicional do princípio constitucional da hierarquia à exclusão da culpabilidade, pelo instituto da obediência hierárquica. Lembra que a conduta do comandante e a consequente obediência hierárquica dos subordinados formam relação bilateral, isto é, o dever legal de mando e o dever de obediência, tendo como suporte a lei: o inferior deve obedecer à ordem do superior, porque a lei ou regulamento assim estatui a relação de mando-obediência ${ }^{23}$.

Em breve resumo, o instituto da obediência hierárquica no Direito Penal Militar merece os seguintes destaques: a) a excludente de culpabilidade, da obediência hierárquica pode ser invocada, por exemplo, em situações de iminência de perigo, calamidade, para salvar vidas ou a unidade militar, ou evitar prática de delitos, respondendo pelo crime o executor da ordem; b) os tipos penais militares de insubordinação, de motim, podem levar à responsabilização dos inferiores se praticarem ato inequivocamente criminoso como, por exemplo, o crime de insubordinação ou motim ${ }^{24}$. c) o Direito Penal Militar brasileiro adota a teoria sincrética considerada como critério intermediário perante a teoria das baionetas inteligentes e da obediência cega.

A primeira permite ao militar desobedecer às ordens não objetivamente legítimas, ao passo que a segunda obriga o militar ao cumprimento das ordens, mesmo ilícitas. De acordo com a teoria sincrética, permitirse-á à pessoa considerada inferior o exame do caráter delituoso do ato ordenado, se a conduta se apresentar como manifestamente criminosa.

De fato, o inferior não pode agir sem raciocínio e sem vontade própria, pois a subordinação e a dependência militares, oriundas dos princípios de hierarquia e disciplina, não podem tornar os subordinados meros executores de ordens. É que, nem em tempo de guerra o Direito Internacional Público aceita o instituto da obediência hierárquica para exculpar condutas atrozes, quer da população civil, quer dos prisioneiros de guerra. Em tempo de paz, por não se constituir em situação excepcional, de emergência, com mais razão, não se consentem tais atos de forças armadas.

\footnotetext{
${ }^{23} \mathrm{O}$ Código Penal Militar prevê a inexistência de culpabilidade quando o inferior age em obediência estrita à ordem de superior hierárquico em matéria de serviços, no caso de ação delituosa, desde que o ato não seja manifestamente criminoso.

${ }^{24}$ Nesse sentido, extrai-se de precedente do superior Tribunal Militar: "O reconhecimento da excludente de culpabilidade de obediência hierárquica deve ser utilizado para absolver o subordinado corréu quando a ordem superior não é manifestamente ilegal" (AP n. 301820107020202, rel. Min. Artur Vidigal de Oliveira, DJ 22-3-2013).
} 


\section{O EXPERIMENTO DE STANLEY MILGRAM}

A fim de observar detalhadamente o ato de obedecer, Stanley Milgram realizou experiência na Universidade de Yale que devia envolver milhares de participantes e terminaria sendo repetida em diversas universidades $^{25}$. Na narrativa de Milgram (1983), duas pessoas chegam a um laboratório de psicologia para participar de estudo sobre memória e aprendizado, sendo uma designada como "professor" e outra como "aluno". O responsável pela experiência explica que o estudo está interessado nos efeitos da punição no aprendizado. O aluno é levado a uma sala, colocado em determinada cadeira, os braços amarrados e um eletrodo ligado a seu punho. Recebe a informação de que deve decorar lista específica de pares de palavras; sempre que cometer erro, receberá um choque elétrico de intensidade progressivamente mais forte.

O foco real da experiência é o professor, responsável pela aplicação de choques em faixa de 15 a 450 volts. Quando o aluno responder corretamente, o professor pula para o item seguinte; no caso da outra pessoa der resposta errada, o professor aplica-lhe choque elétrico, devendo começar com o choque mais fraco (15 volts) e aumentar a intensidade cada vez que o outro errar, aplicando choques de 30 volts, 45 volts e assim por diante. $\mathrm{O}$ "professor" é realmente pessoa inocente que foi ao laboratório participar da experiência, e o aluno, ou a vítima, é um ator, e na verdade não recebe choque algum.

O interesse da experiência é ver até que ponto a pessoa prossegue em situação concreta e mensurável na qual recebe ordem para infligir dor progressivamente maior à vítima que protesta cada vez que recebe o castigo, ou seja, em que ponto a pessoa se recusará a cumprir a ordem recebida?

O conflito surge quando a pessoa que está recebendo os choques começa a demonstrar que está sofrendo. Com 75 volts, o "aluno" geme; com 120 volts, ele reclama verbalmente; com 150, pede para sair da experiência. Seus protestos prosseguem à medida que os choques aumentam de intensidade e tornam-se, então, veementes e emocionais; com 285 volts, sua reação pode ser descrita apenas como grito agonizante. Para se livrar da situação, o professor terá de romper com a autoridade.

O objetivo da pesquisa é descobrir quando e como as pessoas contestariam a autoridade em face de nítido imperativo moral. Por que alguém em seu juízo perfeito aplicaria mesmo o primeiro choque, em vez de se recusar a executar a ordem e sair do laboratório. O fato é que, a despeito de muitas pessoas sentirem stress e de muitas delas protestarem com o pesquisador, parcela substancial continua com o teste até o último choque do gerador.

\footnotetext{
${ }^{25}$ A controvérsia sobre a obediência à autoridade é encontrada em diferentes períodos históricos, o que retira o caráter de originalidade na pesquisa experimental de Milgram, mas torna bem visível sua importância para diferentes áreas do conhecimento além da psicologia.
} 
Há também outro aspecto a ser destacado na experiência de Milgram no que diz respeito às interpretações iniciais de que as pessoas que aplicaram os choques mais fortes às vítimas eram monstros, os sádicos da sociedade, avaliações que não se sustentaram. Ficou constatado que quase dois terços dos participantes se enquadravam na categoria de pessoas "obedientes" e que representavam pessoas comuns, escolhidas entre camadas operárias, de dirigentes e de profissionais liberais.

O que o próprio Milgram reconheceu é que essa particularidade é em grande parte reminiscência da questão surgida com respeito ao livro de Hannah Arendt, de 1963, "Eichmann em Jerusalém”, no qual a autora argumenta que os esforços da promotoria para descrever Eichmann como monstro e sádico estavam fundamentalmente errados, que ele era mais um burocrata sem criatividade que simplesmente se sentava a sua mesa e fazia seu trabalho.

Eichmann, na visão de Arendt (1999), com seus dotes mentais bastante modestos, era certamente o último homem na sala de quem se podia esperar que viesse agir por conta própria e, como além de cumprir aquilo que ele concebia como deveres de um cidadão respeitador das leis, ele também agia subordinado a ordens, acabou completamente confuso e terminou por frisar alternativamente as virtudes e os vícios da obediência cega, ou da "obediência cadavérica".

Sabe-se que, por assumir essa posição, Arendt tornou-se alvo de escárnio, até mesmo de calúnias. Contudo, sentia-se que as coisas monstruosas feitas por Eichmann só poderiam ser executadas por personalidade brutal, alterada, sádica, o próprio mal encarnado.

A partir de certo paralelismo com a posição de Eichmann, destaca-se a figura de Filinto Müller, o temido chefe de polícia da Ditadura de Getúlio Vargas, tratado na biografia lançada por Rose (2017) como "O homem mais perigoso do país", a espécie humana que se reproduz com impressionante intensidade nas ditaduras e tem por habitat as cercanias dos cativeiros: o homem que executa as ordens que vêm de cima, quaisquer ordens, sem jamais contestá-las, sem remorsos, sem crises de consciência, sem hesitação, aquele que levou, a mando de Vargas, Olga Benário, mulher de Luís Carlos Prestes à Alemanha, onde seria assassinada em campo de concentração.

Milgram conclui que, depois de ver centenas de pessoas comuns submetidas à autoridade em suas próprias experiências, a concepção de Arendt sobre a banalidade do mal está mais próxima da verdade do que jamais foi possível imaginar. Diz expressamente que a pessoa comum que aplicou choque em outra assim agiu sem o sentido de obrigação - no conceito de seus deveres como pessoa - e não por meio de qualquer tendência agressiva em especial. 


\section{UM OLHAR SOBRE A OBEDIENCIA HIERÁRQUICA NO DIREITO PENAL BRASILEIRO A PARTIR DO EXPERIMENTO DE STANLEY MILGRAM}

Para pôr em relevo a reflexão sobre o experimento de Milgram, e que o pilar fundamental do tema aqui abordado consiste em propor hipóteses de aplicação da experiência sobre obediência à autoridade, examina-se então os limites da obediência hierárquica no Direito Penal à luz do experimento de Milgram. É o Direito interpretado a partir de narrativa do cinema. Como afirma Araújo (2013), relaciona-se o Direito a outros campos do conhecimento como, por exemplo, a Economia e a Literatura, a fim de importar novos paradigmas de áreas aparentemente isoladas do saber.

Prevista no Código Penal brasileiro como causa excludente da culpabilidade, e quase unânime na doutrina quanto a esse entendimento, diferente de posicionamentos na Alemanha, Itália e Espanha, com defesa da natureza jurídica da obediência hierárquica como causa de exclusão da ilicitude, a ilegalidade da ordem é aplicada apenas para quem a expediu, e não se comunica tal circunstância ao agente executor. Pois bem, o experimento de Milgram traz à evidência o que parecia improvável para a comunidade científica: o fato de que pessoas comuns, simplesmente cumprindo seus deveres, podem se tornar agentes de um terrível processo destrutivo e, mesmo quando esses efeitos ficam claros e há pedido para realizar atos incompatíveis com a moral, as pessoas não resistiam à autoridade, sentindo-se responsáveis por suas próprias ações.

Porém, qual a relevância das conclusões do experimento de Milgram sobre o tratamento dispensado ao instituto da obediência hierárquica no Direito Penal brasileiro? Subjacentemente a esse questionamento está a premissa básica de que, como sentencia Rival (1997), toda teoria deve expor-se a sua própria refutação e, em última análise, só a experiência pode traçar essa linha, mesmo que aproximativamente, daí a importância vital do experimento na história da pesquisa científica, com a observação de que o experimento científico nunca decide o debate epistemológico.

A questão que se coloca aqui é que não há como aceitar-se excluir a culpabilidade do agente que age em estrita obediência à ordem não manifestamente ilegal de superior hierárquico, sem exame dos aspectos psicológicos de sua conduta ${ }^{26}$. O que a norma jurídica penal estabelece, sustentada por qualificada doutrina, é a prevalência ou, com mais exatidão, exclusividade de critérios subjetivos (ordem não manifestamente ilegal emanada de autoridade competente) para isentar o agente de pena, ou, como defende Reale Júnior (2012), a própria exclusão da ilicitude. Nenhuma preocupação com o aspecto comportamental do agente obediente.

Milgram instiga o debate penal mergulhado no marasmo ao mostrar que o mais comum ajuste de

\footnotetext{
${ }^{26}$ É fundamental destacar que Milgram levanta questão em seu experimento sobre a função psicológica da obediência, as condições que the dão forma, os mecanismos de defesa e suas implicações, as forças emocionais que mantem uma pessoa obedecendo.
} 
pensamento na pessoa obediente é sentir-se responsável por suas próprias ações, agindo de maneira moralmente responsável, mas como agente de autoridade externa, o que constitui a essência da obediência, ou seja, a pessoa que se vê como o instrumento de realização dos desejos de outra pessoa, e a partir daí a primeira pessoa não se acha mais responsável por suas ações.

Para o Direito Penal, o agente tem de ter consciência da aparência de licitude da ordem para ser isento de pena. Milgram demonstra que a obediência é compelida pelo medo, que é a vontade assumida na ausência de ameaça de qualquer tipo, mantida através da simples afirmativa, pela autoridade, de que existe o direito de exercer controle sobre a pessoa ${ }^{27}$. Estabelece limites à obediência em seu experimento ao criar fronteira entre a "vítima" e o aplicador dos choques, mas nenhuma iniciativa foi suficiente para levar à desobediência ${ }^{28}$. Alicerçando-se no direito à desobediência civil, Thoreau (2012) questiona: leis injustas existem, mas devemos nos contentar em obedecê-las, ou nos empenhar em aperfeiçoá-las, obedecendo-as até obtermos êxito? Ou devemos transgredi-las imediatamente?

Há dúvida capital que acompanha a doutrina penal e que o experimento de Milgram oferece subsídio para seu deslinde: o que leva a pessoa a obedecer ao superior hierárquico? Com base na conduta diante do pesquisador, a experiência demonstra que há determinados fatores que "amarram" o sujeito à situação ${ }^{29}$, entre os quais estão: a polidez, o desejo de manter a promessa inicial de ajudar o pesquisador e o embaraço de abandonar o teste, evidências suficientes para concluir que o agente que obedece à ordem não manifestamente ilegal de superior hierárquico pouca relevância atribui à natureza da ordem e a suas consequências.

Essa é, a propósito, a conexão que se tenta estabelecer na tese que se defende neste artigo com apoio no filme sobre o experimento de Milgram: o fator psicológico entre o executor da ordem e o ato por ele cumprido ${ }^{30}$.

Com o mesmo enfoque, observa-se que a concepção psicológica de culpabilidade implica, segundo Daufemback (2017), vínculo de natureza psicológica entre o sujeito e o ato por ele praticado, de forma que a culpabilidade somente existiria no autor. Pogrebinschi (2013), ao tratar do problema da obediência em Thomas Hobbes, defende que não há de se falar em contrato, e tampouco em contrato social, mas em pacto de obediência

\footnotetext{
${ }^{27}$ De forma muito apropriada, o autor lembra que o extermínio dos judeus europeus pelos nazistas é o pior exemplo de atos imorais abomináveis executados por milhões de pessoas em nome da obediência. Contudo, em escala menor, esse tipo de coisa continua a ocorrer com frequência: cidadãos comuns recebem ordens para destruir outras pessoas, e assim fazem porque acham que é sua obrigação cumprir as ordens. Assim sendo, a obediência à autoridade, sempre elogiada como uma virtude assume um novo aspecto ao servir a uma causa má; longe de ser uma virtude, é dessa forma transformada em um horrendo pecado.

${ }^{28} \mathrm{O}$ autor ainda chama a atenção para o fato de que a obediência, devido a sua onipresença, é facilmente observada com objeto de pesquisa na psicologia social.

${ }^{29}$ Milgram diz que há uma tendência em pensar que tudo que uma pessoa faz é devido aos sentimentos ou ideias dentro da pessoa, mas, às vezes, suas ações dependem, igualmente, da situação na qual ela se encontra e, neste caso, o poder da situação oprime o seu poder pessoal.

${ }^{30} \mathrm{Na}$ reflexão que faz sobre cinema e psicanálise, Dunker anota que o termo em Hegel para experiência é Ehrfahrung, que vem de fahren, viajar, vaguear ou realizar uma jornada e, ambiguamente, ele designa tanto o processo quanto seu resultado.
} 
através do qual os homens consentem na obediência das leis de natureza, e quando não há poder visível capaz de mantê-los em respeito força-os, por medo ao castigo, ao cumprimento de seus pactos e ao respeito às leis de natureza ${ }^{31}$, e consentem também na instituição da soberania.

A compreensão do argumento contratualista de Hobbes parece ser via possível para encarar seu pensamento como sistema coerente e também para - ao contrário do que fez a imensa maioria de seus comentadores - não negligenciar nem considerar absurda ou incoerente toda a segunda metade do "Leviatã" ou toda a terceira parte do "De Cive". O pacto de obediência hobbesiano é "pacto de cada homem com todos os homens" 32 cujo objeto é o cumprimento das leis de natureza.

\section{CONCLUSÃO}

Tratou-se neste artigo do instituto da obediência hierárquica no Direito Penal brasileiro, disciplinada também no Direito Penal Militar, a partir das conclusões do experimento realizado pelo psicólogo americano Stanley Milgram, reflexões que permitiram apontar a omissão na lei penal do Brasil sobre aspectos relevantes que justificam a isenção de pena daquele que é incriminado por fato, no qual ficou caracterizada a obediência à ordem ilegal, mas que lhe pareceu legal no momento da prática delituosa.

Foi possível estabelecer análise crítica e comparativa, de um lado, entre lei, doutrina e jurisprudência, e, por outro lado, a experiência realizada sobre obediência à autoridade, cuja área de interesse era verificar até que ponto a pessoa é capaz de infligir sofrimento a outra, ou seja, quais os limites do cumprimento da ordem? Como alguém consegue contestar a autoridade diante de claro imperativo moral? Assim, a questão fundamental e decisiva que constitui a problematização do objeto deste artigo levou em consideração a necessidade de se estabelecer limites para o reconhecimento da exclusão da culpabilidade do agente que pratica fato em estrita obediência à ordem não manifestamente ilegal de superior hierárquico.

É lição clássica do Direito estabelecer a ponderação adequada em busca da aproximação da realidade jurídica com a realidade social. A utilização da literatura e do cinema, neste caso, desvenda fatos relacionados à obediência que jamais foram investigados de forma científica. Na verdade, como alude Colombo (2003), a obediência ou a sujeição tornam-se tão familiares que a maioria dos homens nunca investiga sua origem ou sua causa, nem mesmo o princípio de gravidade, de resistência, ou a maioria das leis universais da natureza.

A contestação construída neste artigo procurou analisar edificações paradigmáticas a respeito da obediência hierárquica, buscando chamar a atenção para o fato de que, na direção do que aponta Gérard (2014),

\footnotetext{
${ }^{31}$ Leviatã, XVII, 1.

${ }^{32}$ Leviatã, XVII, 13.
} 
se a obediência é pensada e livremente consentida, ela pode ser recusada ou, em outras palavras, a pessoa que obedece e ao mesmo tempo julga é capaz de parar de obedecer quando percebe que as condições mudaram.

Em síntese, a experiência científica escolhida para confrontar o estatuto penal que positivou a excludente de culpabilidade pela obediência hierárquica, realça a fragilidade do fundamento axiológico da norma posta, contradiz os especialistas e fortalece o argumento de que a obediência não está limitada pela consciência da ilegalidade da ordem, mas pela simples sujeição à autoridade, materializada pela transferência da responsabilidade pelo ato praticado ${ }^{33}$.

Na verdade, o que se sabe com certeza, graças a Milgram, diz Bauman (1998), é que os sujeitos dessas experiências continuaram a cometer atos que reconheciam como cruéis unicamente porque recebiam ordens para fazê-lo, ordens de autoridade que aceitavam e que investiam de responsabilidade última por suas ações, ou seja, os estudos confirmam fato essencial: o fator decisivo é a resposta à autoridade, mais do que a resposta à ordem específica de dar o choque. Enfim, não é o que os sujeitos fazem, mas para quem fazem é o que importa realmente.

\title{
AN ANALYSIS OF THE LIMITS HIERARCHICAL OBEDIENCE IN CRIMINAL LAW IN THE LIGHT OF THE MILGRAM EXPERIMENT
}

\begin{abstract}
Through this article, will be elaborated an analysis of the limits Hierarchical Obedience in criminal law in the light of the Milgram Experiment. The choice of topic is justified because it is understood as a question considered in the Brazilian criminal-law world and, to a certain extent, little explored in the academic environment. This research aims to show, initially, that the Brazilian Penal Code incurs the omission on relevant aspects justifying the agent's penalty exemption. To demonstrate this incongruity, a comparison is made between criminal law, doctrine and criminal jurisprudence and the results of the Milgram Experiment, with an emphasis on the limits within which it is possible to accept the recognition of an exclusion of guilt under the pallium of hierarchical obedience. The problem found in the approach is the prediction of hierarchical obedience in common and military criminal law,
\end{abstract}

\footnotetext{
${ }^{33}$ Poder-se-ia, ainda, questionar se o pilar fundamental do tema objeto deste artigo estaria sujeito às hipóteses de aplicação da famosa Fórmula de Radbruch, tanto a original quanto a pensada por Robert Alexy, considerando que se vislumbra aqui um conflito entre justiça e certeza jurídica diante do direito à exclusão da culpabilidade, expresso na norma penal, de conteúdo visivelmente injusto e ilegalidade positivada, contexto que exige análise conceitual e exame mais aprofundado quanto às teorias sobre a natureza do direito.
} 
thus giving rise to the need to question the recognition of an exclusion of guilt under the pallium of hierarchical obedience. The methodology used is analytical, empirical, with legal and normative concepts in the scope of law and psychology. The concepts used take into account the social reality, as well as the doctrinal and jurisprudential understanding on the matter. It is hoped to obtain as a result of the work to clarify the importance of the correct application of the hierarchical obedience institute, considering the change in the penal law.

Keywords: Criminal Law; Guilt; Hierarchical obedience; Milgram experiment.

\section{REFERENCIAS}

ARENDT, Hannah. Eichmann em Jerusalém: um relato sobre a banalidade do mal. São Paulo: Companhia das Letras, 1999.

ARAÚJO, Régis Frota. Direitos fundamentais, cinema e literatura: propostas interdisciplinares II. Fortaleza: Imprensa Universitária, 2013.

BARROS, Francisco Dirceu; CINTRA, Antônio Fernando. Direito Penal: interpretado pelo STF e STJ. Leme: J. H. Mizuno, 2016.

BAUMAN, Zygmunt. Modernidade e Holocausto. Rio de Janeiro: Zahar, 1998.

BITENCOURT, Cezar Roberto. Tratado de Direito Penal: parte geral. v. 1. São Paulo: Saraiva, 2007.

COLOMBO, Eduardo. Anarquismo, obrigação social e dever de obediência. São Paulo: Imaginário, 2003.

DAUFEMBACK, Valdirene. Psicologia e Direito: o uso dos conceitos psicológicos no Direito Penal. Belo Horizonte: D'Plácido, 2017.

DELMANTO, Celso. Código Penal comentado. Rio de Janeiro: Renovar, 2007. 
DUNKER, Christian Ingo Lenz; RODRIGUES, Ana Lúcia. A realidade e o real: verdade em estrutura de ficção. Coleção Cinema e Psicanálise: v. 2. São Paulo: nVersos, 2015.

FIGUEIREDO, Telma Angélica. Excludentes de ilicitude e obediência hierárquica no Direito Penal Militar. Rio de Janeiro: Lumen Juris, 2009.

FLORES, Andréa. Manual de Direito Penal. Coleção Ícones do Direito. São Paulo: Saraiva, 2016.

FRAGOSO, H. C. Jurisprudência criminal. Rio de Janeiro, 1982.

Lições de Direito Penal - nova parte geral. Rio de Janeiro, Forense, 1995.

GARCIA, B. Instituições de Direito Penal. São Paulo: Max Limonad, 1980.

GÉRARD, Valérie. Obedecer? Rebelar? São Paulo: Alaúde, 2014.

GOMES, Luiz Flávio. Direito Penal: parte geral: v. 2. São Paulo: Revista dos Tribunais, 2007.

GONÇALVES, Victor Eduardo Rios. Curso de Direito Penal: parte geral, v. 1. São Paulo: Saraiva, 2015.

GRECO, Rogério. Curso de Direito Penal. Rio de Janeiro: Impetus, 2014.

JUNQUEIRA, Gustavo. Manual de Direito Penal: parte geral. São Paulo: Saraiva, 2017.

KOERNERJÚNIOR, Rolf. Obediência hierárquica. Belo Horizonte: Del Rey, 2003.

MARTINELLI, João Paulo Orsini; SCHMITT, Leonardo. Lições fundamentais de Direito Penal: parte geral. São Paulo: Saraiva, 2017.

MARTINS. José Salgado. Direito Penal. São Paulo: Saraiva, 1974.

MAYRINK DA COSTA, Álvaro. Direito Penal: v. 1 - parte geral. Rio de Janeiro: Forense, 2005. 
MILGRAM, Stanley. Obediência à autoridade: uma visão experimental. Rio de Janeiro: F. Alves, 1983.

MILHOMEN, Flávio. Direito Penal Direto e Objetivo. Brasília: Alumnus, 2014.

MUNHOZ NETTO, Alcides. A ignorância em matéria de antijuridicidade em matéria penal. Rio de Janeiro: Forense, 1978.

NUCCI, Guilherme de Souza. Curso de Direito Penal - parte geral: arts. $1^{\circ}$ a 120 do Código Penal. Rio de Janeiro: Forense, 2017.

PIRES, Ariosvaldo de Campos. A coação irresistível no Direito Penal brasileiro. Belo Horizonte: Lemi, 1973.

POGREBINSCHI, Thamy. O problema da obediência em Thomas Hobbes. Bauru/SP: EDUSC, 2003.

QUEIROZ, Paulo. Direito Penal: parte geral. São Paulo: Saraiva, 2005.

REALEJÚNIOR, Miguel. Instituições de Direito Penal. Rio de Janeiro: Forense, 2012.

ROSE, R. S. O homem mais perigoso do país: biografia de Filinto Müller. Rio de Janeiro: Civilização Brasileira, 2017.

TELES, Ney Moura. Direito Penal: parte geral: arts. $1^{\circ}$ a 120, v. 1. São Paulo: Atlas, 2006.

THOREAU, Henry David. A desobediência civil. São Paulo: Penguin Classics, Companhia das Letras, 2012.

TURNER, Graeme. Cinema como prática social. São Paulo: Summus, 1997.

VARGAS, J. C. Instituições de Direito Penal - parte geral. Tomo I. Belo Horizonte: Del Rey, 1977.

Trabalho enviado em 17 de julho de 2018

Aceito em 19 de setembro de 2018 